\title{
Study of approaches to incipient fault detection in power transformer by using dissolved gas analysis
}

\author{
Ruta Liepniece, \\ Sandra Vitolina, \\ Janis Marks \\ Riga Technical University, \\ Azenes St. 12/1, \\ LV-1048 Riga, Latvia \\ E-mail: ruta.liepniece@edu.rtu.lv
}

To maintain the reliability of power transmission it is important to detect the incipient fault of power transformer as early as possible. If the fault of a power transformer is not detected promptly, it can evolve resulting in high repair costs or even failure of the power transformer and decreasing reliability of power transmission. The most commonly used method for power transformer fault detection is the dissolved gas analysis (DGA) of transformer oil. Various methods have been developed to interpret the data of dissolved gas analysis, but not many are applicable for the detection of the incipient fault.

The detection of the incipient fault of a power transformer is included in both IEEE C57.104-2008 "Guide for the Interpretation of Gases Generated in Oil-Immersed Transformers" and Standard of Latvian Electrotechnical Committee LEK 118 "Transformer Oil Inspection Standards". In both standards, the limits of dissolved gases in transformer oil are divided into levels, each corresponding to different technical conditions of the power transformer including the level that indicates the incipient fault. However, these approaches vary to a great degree - one approach mostly indicates that transformers are in good condition with several cases that must be additionally evaluated, but the second approach mostly results in warning about the incipient fault, which must be confirmed by additional evaluation.

The objective of this paper is to determine the most suitable approach to detect the incipient fault of power transformers. A case study is provided, which includes analysis of DGA data of 48 power transformers installed in the transmission network in Latvia with both methodologies mentioned above for detecting the incipient fault.

Keywords: power transformers, dissolved gas analysis, incipient fault, reliability

\section{INTRODUCTION}

A power transformer is an essential element in any power transmission system. It affects the reliability of the power system, and the failure of a transformer can cause larger incidents with wide-ranging consequences. Many of power transformers in the power transmission system of Latvia have already been in service for 26-40 years [1]; similar situation also is in the USA, 
Poland and elsewhere in Europe [2-4]. Therefore, it is important to ensure safe operation of power transformers and to detect the incipient faults as early as possible, because when the age of the power transformer increases so does the probability of failure [5]. The market now offers plenty of sensors, on-line continuous monitoring systems, analysis algorithms and software systems for evaluation of condition; however, there is no common practice on how to convert a large amount of data into useful and relevant information [6]. This principle also applies to detecting the incipient fault of a power transformer - operation and maintenance data is accumulated yet a suitable approach has to be selected for interpretation.

Dissolved gas analysis (DGA) is one of the most widely used methods for the periodic assessment of technical condition of oil-filled power transformers, and DGA is also included in the majority of on-line condition monitoring systems [7]. It should be noted that the accuracy of the conclusion about technical condition of a power transformer depends on the used DGA data interpretation method.

There are many methods for the evaluation of DGA data, and the resulting conclusion about technical condition of the power transformer may differ significantly with each method. The widely used classic methods - Rogers method, IEC method, Duval triangle method - mostly are not applicable for the detection of the incipient fault of a power transformer, because the obtained combination of fault gas ratios can indicate one of the fault types (e.g. partial discharge, discharge, thermal fault) for normal operation if the dissolved gas concentration level (in ppm) is low [7].
The objective of this paper is to determine the most suitable approach to detect the incipient fault of a power transformer. In this paper, DGA data of 48 oil-filled power transformers were analysed. These transformers are with the rated voltage of $110 / 20 \mathrm{kV}$ and all of them have an active on-load tap-changer. The rated power of these transformers is within the range from 6.3 MVA to 40 MVA. The DGA data has been provided by the Latvian Transmission System Operator (Augstsprieguma $t \bar{i} k l s$, JSC), and the data is from periodic tests, not from the transformer on-line condition monitoring system. For analysis one DGA data sample is used; however, if additional assessment is required 2 DGA measurements are analysed for a particular transformer. Since all transformers are approximately equally loaded, then the load is not used as a criterion for DGA data interpretation.

\section{STANDARD METHODS FOR INCIPIENT FAULT DETECTION}

Given that each country has a different size of the power transmission system, different number of consumers, construction and age of installed power transformers, climate and other factors affecting transformer operating conditions that can influence the generation of dissolved gases in transformer oil, each country has adopted different fault gas concentration limits in their power systems [8].

The technical condition assessment of power transformers in Latvia is regulated by national standard LEK 118 "Transformer Oil Inspection Standards" issued by the Latvian Electrotechnical Committee in which the limits of fault gas concentration are divided into 3 levels (Table 1).

Table 1. Dissolved gas concentrations in LEK 118 for 110-330 kV power transformers, ppm

\begin{tabular}{|c|c|c|c|c|c|c|c|c|c|}
\hline Level & $\mathrm{H}_{2}$ & $\mathrm{CH}_{4}$ & $\mathrm{C}_{2} \mathrm{H}_{2}$ & $\mathrm{C}_{2} \mathrm{H}_{4}$ & $\mathrm{C}_{2} \mathrm{H}_{6}$ & CO & $\mathrm{CO}_{2}$ & TDCG & Explanation \\
\hline L1 & $<60$ & $<45$ & $<1$ & $<15$ & $<30$ & $350(400)^{* *}$ & $<1500$ & 100 & $\begin{array}{c}\text { Normal operation } \\
\text { of a transformer }\end{array}$ \\
\hline L2 & $60-100$ & $45-100$ & $1-10$ & $15-70$ & $30-50$ & $\begin{array}{l}350-500 * * \\
(400-600)\end{array}$ & $1500-3800$ & $100-315$ & $\begin{array}{l}\text { Detection of } \\
\text { incipient fault }\end{array}$ \\
\hline L3 & 100 & 100 & 10 & 70 & 50 & $\frac{500^{*}}{600}$ & $\frac{6000(2000)^{* *}}{8000(4000)}$ & $>315$ & $\begin{array}{l}\text { Detection of } \\
\text { existing fault }\end{array}$ \\
\hline
\end{tabular}


The methodology of LEK 118 states that the interpretation of DGA data is carried out by evaluating the concentrations of dissolved gases in oil and with the Key Gas method, gas ratio methods and Duval triangle method [9].

In the framework of this research DGA data of 48 oil-filled power transformers has been interpreted by using the dissolved individual gas in oil concentration limits stated in LEK 118. The results are shown in Fig. 1, where C1 corresponds to normal operation of the transformer, $\mathrm{C} 2$ is detection of the incipient fault, and $\mathrm{C} 3$ is detection of the existing fault. The results indicate that only for 10 of 48 transformers the condition is indexed as normal operation, while other transformers were identified either with an incipient or existing fault. The obtained results conflict with real maintenance situation since additional tests or repair works were not appointed based on DGA measurement results.

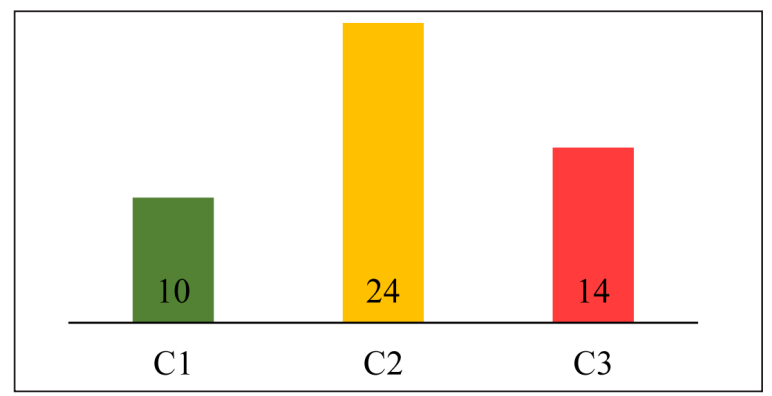

Fig. 1. Results of DGA data interpretation by method recommended in LEK118

The total dissolved combustible gas (TDCG) concentrations for each level are listed in LEK 118 (Table 1), but these concentrations are not used in the current DGA interpretation method. Since the results indicate that alterations in the current interpretation method are necessary, TDCG was included as an additional evaluation parameter.

TDCG is the sum of total dissolved combustible gases in transformer oil - hydrogen $\mathrm{H}_{2}$, methane $\mathrm{CH}_{4}$, ethane $\mathrm{C}_{2} \mathrm{H}_{6}$, ethylene $\mathrm{C}_{2} \mathrm{H}_{4}$, acetylene $\mathrm{C}_{2} \mathrm{H}_{2}$ and carbon monoxide $\mathrm{CO}$, except carbon dioxide $\mathrm{CO}_{2}$, because it is not combustible gas. The amount of TDCG may indicate the existence of combination of thermal and/or electrical faults or any singular fault.

The application of TDCG as a parameter for the evaluation of transformer condition is described in standard IEEE C57.104 2008 "Guide for the Interpretation of Gases Generated in Oil Immersed Transformers" [10]. In IEEE C57.104, 4 levels are defined: Level 1 indicates normal operation of the transformer, Level 2 is detection of the incipient fault, Level 3 indicates increased suspicion of the incipient fault, and Level 4 is detection of the existing fault. The methodology of IEEE C57.104 states that the interpretation of DGA data is carried out gradually, and the first step is determining the value of TDCG, followed by analysis of individual fault gas concentrations. Any individual fault gas exceeding Level 1 should prompt additional investigation by the Key Gas method, gas ratio methods or determination of TDCG generation rate.

\section{PROPOSED APPROACH FOR THE EVALUATION OF DGA DATA}

In the framework of this research TDCG was proposed as an additional evaluation parameter to improve reliability of the existing DGA data interpretation approach recommended in national standard LEK 118. It has to be noted that TDCG values recommended in LEK 118 are significantly lower than the sum of combustible gases in each level (Table 1), while in standard IEEE C57.104, TDCG values slightly exceed the sum of combustible gases in each level.

The limits of TDCG values shown in Table 2 and used for DGA data analysis of 48 oil-filled power transformers are obtained by following IEEE guidelines. The results of data interpretation are shown in Fig. 2 and indicate that for 42 of 48 transformers operation is indexed as normal, which better complies with maintenance data. However, in many cases at least one of fault gases exceeds concentrations of Level 1, which implies that further analysis is required. The trend of total dissolved combustible gas (TDCG) generation rate and acetylene $\mathrm{C}_{2} \mathrm{H}_{2}$ concentration are proposed as criteria for this additional evaluation.

Table 2. Proposed TDCG concentrations

\begin{tabular}{c|c}
\hline Level & TDCG, ppm \\
\hline L1 & $<501$ \\
\hline L2 & $501-860$ \\
\hline L3 & $>860$ \\
\hline
\end{tabular}




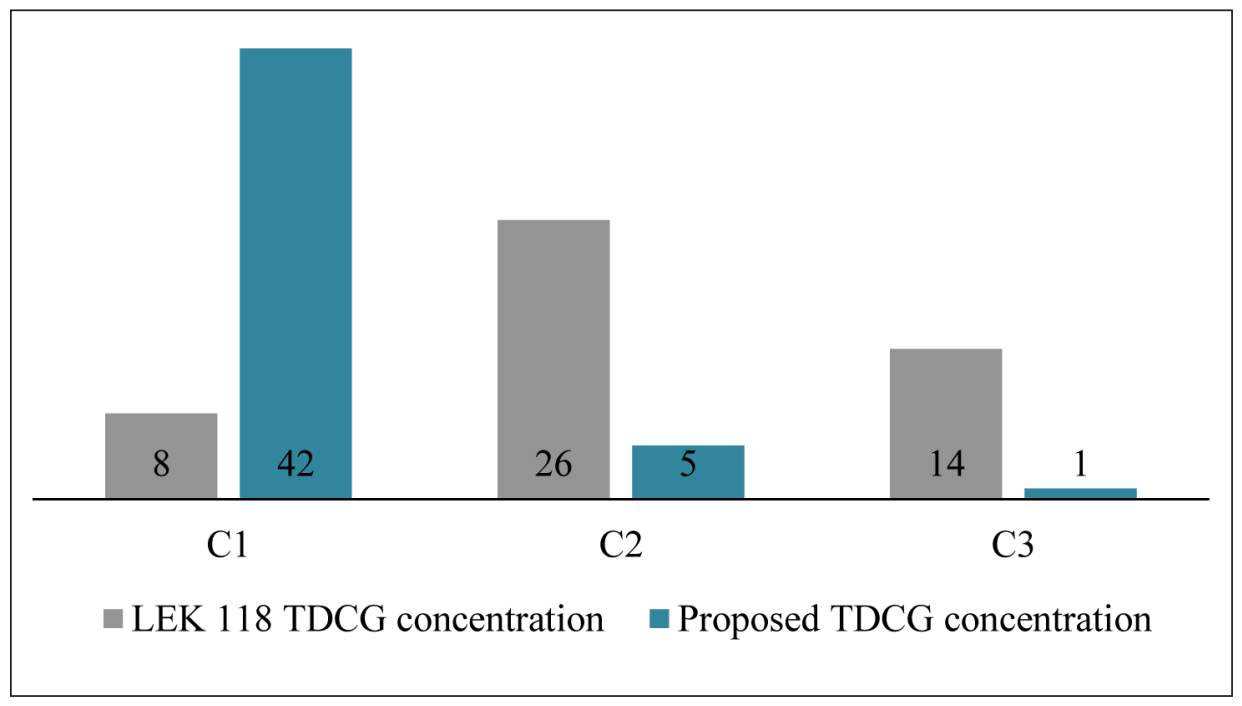

Fig. 2. Results of DGA data interpretation based on TDCG values

Fault gases may generate in greater amounts during normal operation in transformers with an on-load tap-changer (OLTC) than in transformers without it, because contacts of OLTC heat up during operation resulting in discharges in transformer oil. Acetylene concentration for Level 1 is only 1 ppm (see Table 1 ), so it has been observed that acetylene concentration in transformers with OLTC usually exceeds this value, indicating an incipient fault although the operation of the unit is normal. To exclude the possibility of false alarm, additional acetylene control is proposed in this paper. A flowchart for the proposed approach for the evaluation of DGA data is shown in Fig. 3.

The first step of the proposed algorithm (see Fig. 3) is indexing transformer condition based on the value of TDCG - either it is Condition 1 (C1), Condition 2 (C2) or Condition 3 (C3). The second step is the evaluation of individual fault gases in transformer oil, and transformer condition is defined more accurately - either it is Condition $1\left(\mathrm{C} 1^{*}\right)$, Condition $2\left(\mathrm{C} 2^{*}\right)$ or Condition $3\left(\mathrm{C}^{*}\right)$. In cases when $\mathrm{Cn}$ and $\mathrm{Cn}^{*}$ do not match, the third step of the proposed approach is applied, which is additional evaluation by the trend of total dissolved combustible gas (TDCG) generation rate and acetylene $\mathrm{C}_{2} \mathrm{H}_{2}$ concentration, and transformer condition obtains either Condition $1\left(\mathrm{Cl}^{\star *}\right)$, Condition 2 $\left(\mathrm{C} 2^{\star *}\right)$ or Condition $3\left(\mathrm{C} 3^{\star *}\right)$.

\section{VERIFICATION OF THE PROPOSED APPROACH}

To determine the most suitable approach for the detection of the incipient fault of a power transformer, case studies are provided, which include analysis of DGA data of 48 power transformers installed in the transmission network in Latvia. Case study A represents the results of DGA data interpretation with the approach proposed in Fig. 3 and TDCG concentrations recommended in LEK 118; case study B represents the results of DGA data interpretation with the proposed approach, however TDCG concentrations recommended in LEK 118 are adjusted; case study C represents the results of DGA data interpretation with the proposed approach and TDCG concentrations obtained by following IEEE guidelines.

\section{CASE STUDY A}

At the first case study, DGA data of 48 power transformers were interpreted by using the proposed approach of DGA data evaluation (Fig. 3) with the TDCG values and individual fault gas concentrations recommended in standard LEK 118 (Table 1).

Figure 4 represents the analysis of obtained results, respectively the variance of the number of transformers with detected conditions in each 


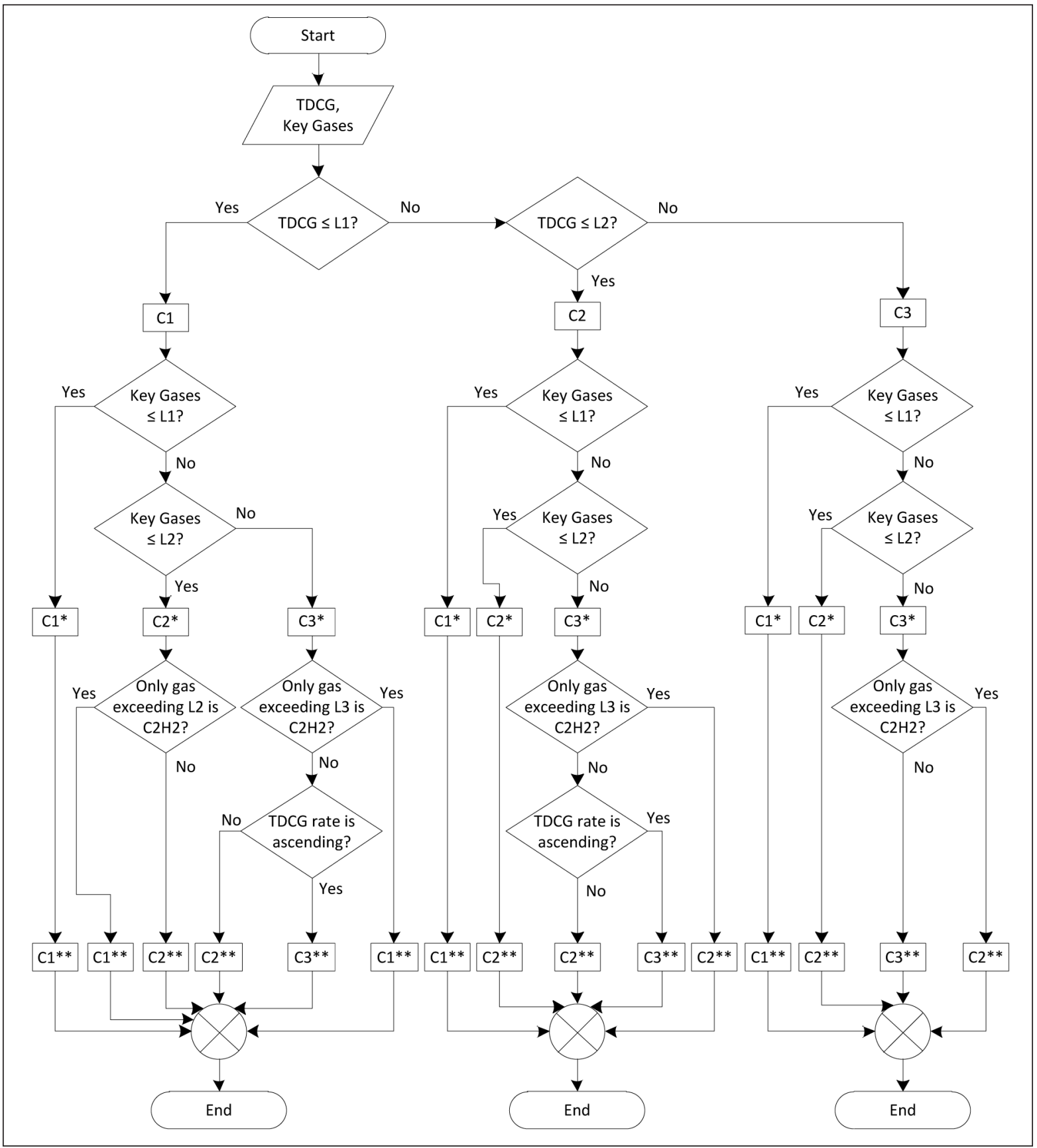

Fig. 3. Flowchart of proposed approach for the evaluation of DGA data

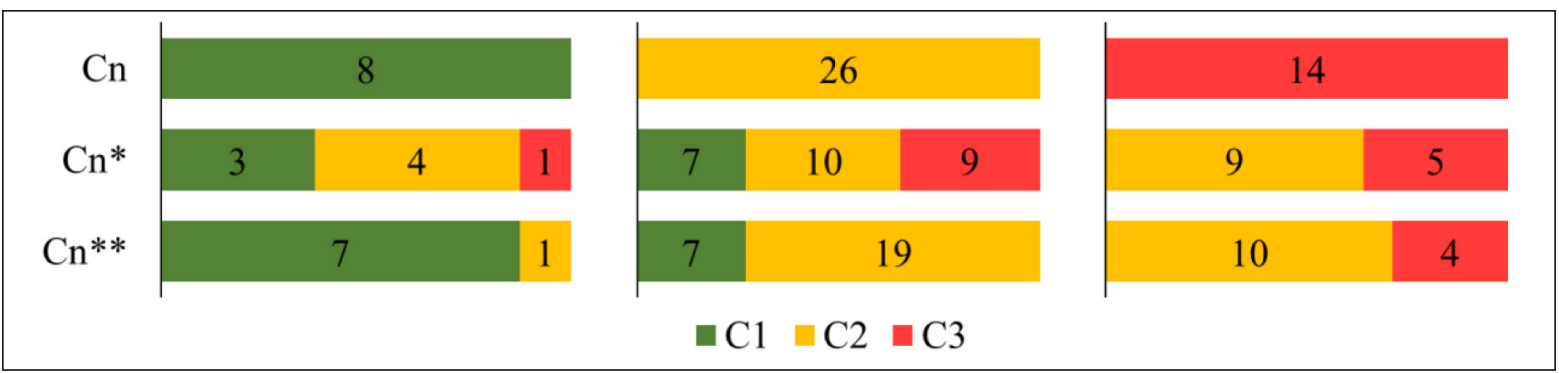

Fig. 4. Results of DGA data evaluation in case study A 
step of the proposed approach. Figure 4 shows that after the first step, the number of transformers with normal operation (C1) is 8 units, but faults are detected (condition C3) for 14 units which corresponds with the results provided in Fig. 2.

After initial analysis of individual fault gases in the second step of the proposed algorithm it was found that for 5 of 8 transformers in condition group $\mathrm{C} 1$ further analysis is required since the level for individual fault gas was either L2 or L3 (see Table 1). The third step of the proposed algorithm evaluation of TDCG trend and the value of acetylene did confirm a possible incipient fault only for 1 transformer. Following the same principle, results for condition groups $\mathrm{C} 2$ and $\mathrm{C} 3$ were obtained.

As a result, the number of transformers that had been diagnosed with the existing fault (C3) decreased by 10 units with the proposed approach of DGA data evaluation compared to the results obtained by analysis of DGA data only with individual fault gases recommended in standard LEK 118 (Fig. 1). The number of transformers that have normal operation increased by 4 units, but there are still a number of transformers which are detected with the incipient fault.

\section{CASE STUDY B}

Another case study involves analysis of the same DGA data with the proposed approach (Fig. 3); however, in this case TDCG values were adjusted. It was proposed to obtain TDCG values by adding up lower concentrations of the interval specified in Table 1 of individual combustible fault gases. Proposed values are given in Table 3.
Table 3. Adjusted TDCG concentrations

\begin{tabular}{c|c}
\hline Level & TDCG, ppm \\
\hline L1 & $<100$ \\
\hline L2 & $100-500$ \\
\hline L3 & $>500$ \\
\hline
\end{tabular}

The results obtained in each step of the proposed approach are presented in Fig. 5; the results were analysed by the same principle as in the chapter above. The number of transformers that were detected with normal operation (C1) is the same because the TDCG concentration of Level 1 was not changed. However, the number of transformers that were detected with the incipient fault $(\mathrm{C} 2)$ in the first step increased by 8 units, because the upper value of TDCG Level 2 concentration was increased.

It can be observed that after completing the last two steps of proposed DGA data evaluation approach, the number of transformers in each group is the same as in case study A. But the use of adjusted TDCG concentration allowed decreasing the number of transformers that must be additionally evaluated in the third step.

\section{CASE STUDY C}

The last case study involves analysis of the same DGA data with the proposed approach (Fig. 3), but the TDCG values used in this case study are given in Table 2 . These values are obtained by adding up the upper concentrations of the interval specified in Table 1 of individual combustible fault gases. The obtained results in each step of the proposed approach are presented in Fig. 6.

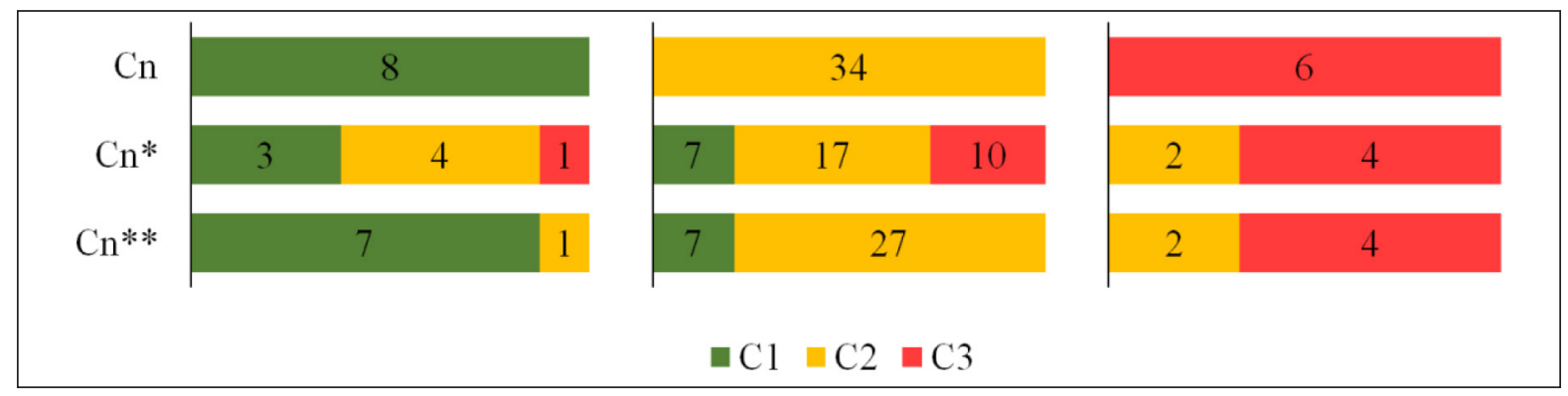

Fig. 5. Results of DGA data evaluation in case study $B$ 


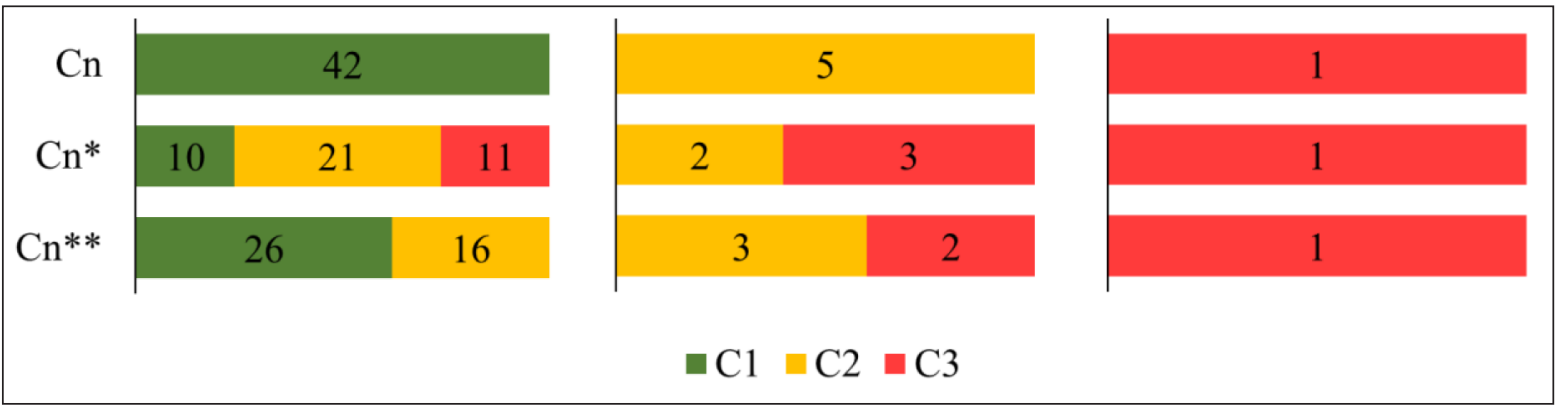

Fig. 6. Results of DGA data evaluation in case study C

It can be observed that in the first step of analysis the majority of transformers are indexed with normal operation (C1) which is completely opposite if compared to case study A and case study B. But after the evaluation of DGA data in the second and the third step of the proposed approach, the number of transformers in this condition group $\mathrm{C} 1$ decreased by nearly $40 \%$.

\section{ANALYSIS OF THE RESULTS}

The results obtained are compared with the results if the method recommended in the national standard is used (see Fig. 7). It can be observed that in case study A and case study B there are many transformers that were detected with the incipient fault. This can be explained by low concentrations of fault gases recommended in standard LEK 118. The proposed TDCG concentration values in case study $\mathrm{C}$ allowed to reduce the number of transformers that were diagnosed with the existing fault (C3) if compared with the obtained results with the current method recommended in standard LEK 118. But it was observed that the approach used in case study $C$ is not so effective, because the number of transformers that must be additionally evaluated in the second and third step of the proposed approach for the evaluation of DGA data increased. Furthermore, by using the proposed TDCG concentrations in case study $\mathrm{C}$, it is easier to miss the transformers that could have the incipient fault compared to the adjusted concentrations in case study B.

\section{CONCLUSIONS}

The approach for the evaluation of DGA data based on the Key Gas method that is recommended in national standard LEK 118 is not

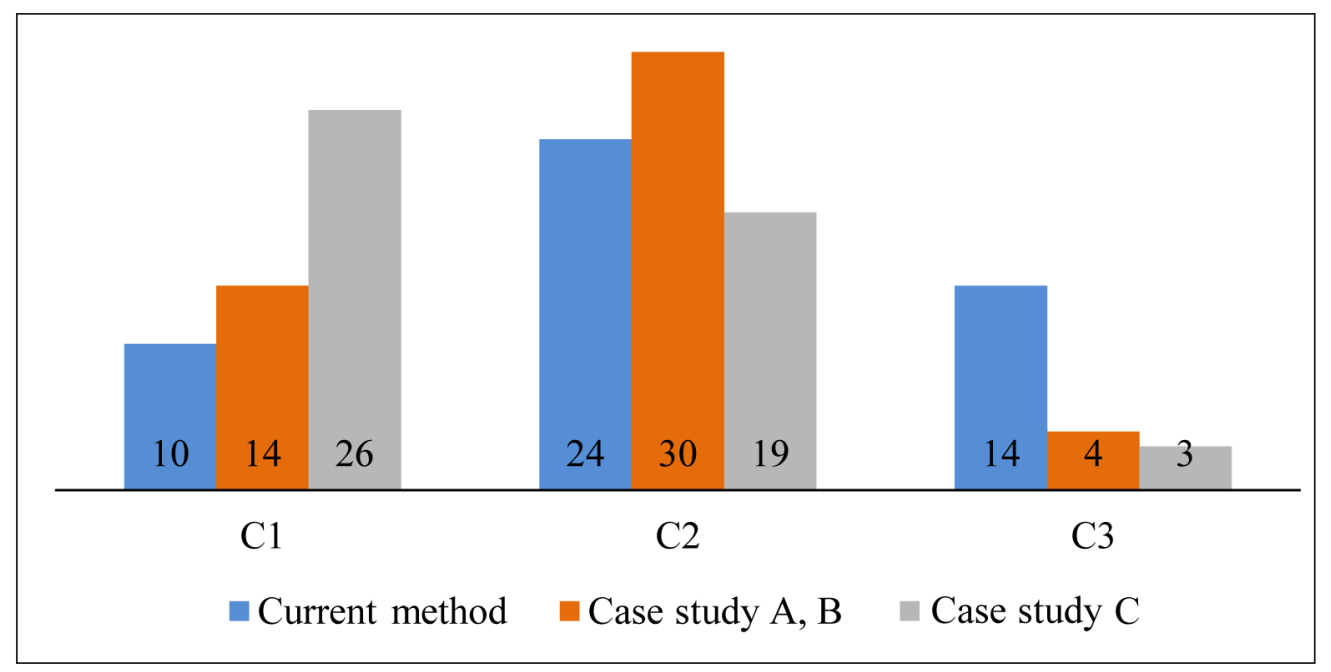

Fig. 7. Results of DGA data evaluation with different approaches 
efficient for the detection of the incipient fault in a power transformer. A different multi-step approach based on ideas of standard IEEE C57.104 is proposed, where the first step is the evaluation of TDCG value, followed by the evaluation of individual fault gases in the second step and additional analysis of acetylene concentration and trend of TDCG generation rate in the final step. The proposed approach allowed decreasing the number of transformers that were mistakenly diagnosed with the existing fault, although their operation was normal.

It is proposed to adjust the upper value of TDCG concentration from $315 \mathrm{ppm}$ to $500 \mathrm{ppm}$ for Level 2 since it resulted in a reduced number of transformers that must be additionally evaluated by the proposed approach without changing the proportion of units in each condition. The proposed values of TDCG concentration used in case study $\mathrm{C}$ require further research because they provide a significantly higher number of transformers with normal operation (C1).

\section{ACKNOWLEDGEMENTS}

The authors express their gratitude to the Latvian Transmission System Operator (Augstsprieguma $t i k l s$, JSC) for providing DGA data for the case studies.

Received 1 March 2017 Accepted 15 May 2017

\section{References}

1. Poiss G., Vitolina S. Overview of the power transformer park and diagnostic methods in Latvia. 5th International Conference on Power Engineering, Energy and Electrical Drives, Riga: Riga Technical University, May 11-13, 2015.

2. Large Power Transformers and the U.S. Electric Grid. April 2014 Update. Infrastructure Security and Energy Restoration Office of Electricity Delivery and Energy Reliability U.S. Department of Energy, 2014 [referred on the 3rd of December in 2016]. <http://www.energy.gov/sites/prod/ files/2014/04/f15/LPTStudyUpdate-040914. pdf>

3. Energy Transfer Potential Assessment and Planning Report. Mazovia Energy Agency, 2014 - [referred on the 3rd of December in 2016]. <http:// www.cep-rec.eu/fileadmin/user_data/CEPREC_dokumente/energy_transfer_potential/ PP13_332_ETPR_PL.pdf>

4. Homagk C., Mössner K., Leibfried T. Investigation on degradation of power transformer solid insulation material. Annual Report Conference on Electrical Insulation Dielectric Phenomena, Quebec, Canada, October 26-29, 2008.

5. Metwally Ibrahim A. Failures, monitoring and new trends of power transformers. IEEE Potentials. 2011. Vol. 30. No. 3. P. 36-43.

6. Guide on Transformer Intelligent Condition Monitoring (TICM) Systems. Technical Brochure 630, CIGRE, 2015.

7. Muhamad N. A., Phung B. T., Blackburn T. R., Lai K. X. Comparative study and analysis of DGA methods for transformer mineral oil, Power Tech. Lausanne, July 1-5, 2007.

8. Duval M. Calculation of DGA limit values and sampling intervals in transformers in service. IEEE Electrical Insulation Magazine. 2008. Vol. 24. Issue 5. P. 7-13.

9. Transformer Oil Inspection Standards (Transformatoru ellu pārbaudes normas). Standard LEK 118, Latvian Electrotechnical Committee, 2014. 45 p. (in Latvian).

10. Guide for the Interpretation of Gases Generated in Oil-Immersed Transformers. Standard IEEE C57.104 ${ }^{\mathrm{TM}}-2008$, Institute of Electrical and Electronic Engineers, 2008. 39 p. 
Ruta Liepniece, Sandra Vitolina, Janis Marks

PRASIDEDANČIO GEDIMO NUSTATYMO

GALIOS TRANSFORMATORIUJE TYRIMAI NAUDOJANT IŠTIRPUSIŲ DUJŲ ANALIZE

\section{Santrauka}

Siekiant užtikrinti elektros perdavimo tinklo patikimumą yra svarbu kuo anksčiau aptikti prasidedantị galios transformatoriaus gedimą. Jeigu galios transformatoriaus gedimas greitai neaptinkamas, jis gali išplisti ir sukelti didelių remonto išlaidų arba netgi transformatoriaus avariją, sumažinti perdavimo tinklo patikimumą. Dažniausiai naudojamas metodas galios transformatoriaus gedimui nustatyti yra transformatoriaus alyvos ištirpusių dujų analizè. Ištirpusių dujų duomenų interpretacijai buvo sukurta įvairių metodų, tačiau tik nedaugelis iš jų yra tinkami prasidedančiam gedimui aptikti.

Prasidedančio galios transformatoriaus gedimo nustatymas yra įtrauktas ị standartus IEEE C57.104-2008 „Alyviniuose transformatoriuose susidarančių dujų vertinimo vadovas“ ir Latvijos elektrotechnikos komiteto standartą LEK 118 „Transformatorių alyvos patikros normos“. Abiejuose standartuose transformatoriaus alyvoje ištirpusių dujų leistinos ribos yra skirstomos ị lygius, atitinkančius skirtingas transformatoriaus technines būkles, įskaitant lygit, kuris žymi prasidedanti gedimą. Tačiau šios metodikos labai skiriasi - viena dažniausiai nurodo, kad transformatoriai yra geros būklès tam tikrais atvejais, kurie turi būti papildomai ịvertinti, o kita metodika paprastai perspeja apie prasidedanti gedimą, kuris turi būti patvirtintas papildomu ivertinimu.

Šio straipsnio tikslas - nustatyti tinkamiausią metodiką, leisiančią aptikti prasidedantị galios transformatoriaus gedimą. Pateikiamas tyrimo pavyzdys, kuris apima ištirpusių dujų duomenų analizę 48 galios transformatoriuose, irrengtuose Latvijos perdavimo tinkle, remiantis abejomis anksčiau minètomis metodikomis prasidedančiam gedimui nustatyti.

Raktažodžiai: galios transformatoriai, ištirpusių dujų analizè, prasidedantis gedimas, patikimumas 